consistent with the principles of building the structure of the world economy, the balance of power on the world stage and the interests of leading economic centers and countries.

The status of the US dollar as the main reserve currency is not in doubt. First, there are no serious macroeconomic and statistical reasons for this yet. Secondly, changes in this direction threaten serious economic problems for all countries, although we are not talking about the crisis of the entire world monetary system (even when the status of the US dollar changes).

Thus, the international foreign exchange market is one of the components of the capital market, which operates without capital intervention. It should be noted that financial crises can provoke an escape to a quality asset. The events of the last year in the world economy have shown that countries should either release their currencies or adopt another currency that will fluctuate freely relative to all others.

At the same time, the main reserve currency in the world - the US dollar - retains its stability: currency exchange regime, conditions of currency convertibility, world currency market regimes, etc.

\title{
References:
}

1.International Monetary Fund : офіц. сайт. Washington, 2010-2016. URL: http://www.imf.org .

2.Jonathan Huntley, CBO Macroeconomic Analysis Division. - Congressional Budget Office, Figure 1 of "Federal Debt and the Risk of a Fiscal Crisis", July 272010.

3.Obstfeld Maurice. Risk and Exchange Rates. NBER. Working paper. 1998. № 6694. 19 p.

4.The Economist. Link by Link: A Short History of Modern Finance. London, 2008 October 16th, pp. 79-81. Available via: http://www.economist.com/displaystory.cfm?story_id=12415730.

5. King, S. Terrible results of the economic beauty contest: Forex market news, 2012. URL: Forexpf.

6. Yaremenko O.O. Features of the concept of "currency regulation" in modern economic conditions. Investments: practice and experience, 2011. №21. Pp. 102-105.

7. Butorina, O.N. Upcoming changes in the international monetary system: Exchange Review, 2014. №4. Pp. 20-35.

8. Bodrova N.E. Currency market: status, problems, prospects, 2012. 103 p.

Дата подання публікації 10.10.2021p.

\section{УДК 339.944:004.9}

Кривов'язюк I.В., к.е.н., професор Професор кафедри підприємництва, торгівлі та логістики Kryvovyazyuk I., PhD in Economics, Professor

Professor of the Department of Entrepreneurship, Trade and Logistics https://orcid.org/0000-0002-8801-4700

\section{ФАКТОРИ УСПІХУ МІЖНАРОДНИХ СТРАТЕГІЧНИХ АЛЬЯНСІВ У IT-СФЕРІ В УМОВАХ ПОШИРЕННЯ COVID-19}

\section{Луцький національний технічний університет}

Міжнародний бізнес в IT-сфері займає все більшу й більшу частку світового ринку, значною мірою завдячуючи розвитку міжфірмової інтеграції, формуванню міжнародних стратегічних альянсів. Реалізація міжгалузевих інноваційних проєктів, формування нових умов взаємодії держав і бізнесу, технологічна інтеграція науки та виробництва дозволяють успішно долати бар'єри економічних блоків і кордони країн, освоювати нові міжнародні ринки збуту.

В науковій статті було вирішене складне завдання - здійснити видову класифікацію факторів успіху міжнародних стратегічних альянсів у IT-сфері в умовах поширення COVID-19. Незважаючи на значну кількість публікацій, присвячених проблематиці формування та розвитку міжнародних стратегічних альянсів, іiі розкривали частково, визначаючи предметну суть стратегічних альянсів, організаційно-правові умови їх формування, переваги й недоліки створення, особливості управління. Зовсім не вирішеною така проблематика постала для сучасних умов - поширення COVID-19. Й не менш важливим $є$ визначення факторів, які сприяють успіху стратегічних альянсів на міжнародних ринках. 
Здійснений в роботі аналіз наявної динаміки та прогнозування світових витрат на IT в період 20202022 рр. виявив значне підвищення інтересу до секторів IT-бізнесу в умовах поширення COVID-19, формування сприятливих умов для інвестування в продукти програмного бізнесу, порівняно з тим, як більшість компаній світу все ще зазнають скорочення доходів. Це, безумовно, підкреслює вагомість вивчення факторів, що сприяли виявленим тенденціям розвитку ІТ-бізнесу і ролі в цьому міжнародних стратегічних альянсів, частка компаній яких становить близько 20\% загальної їх кількості.

В ході дослідження факторів впливу на формування та розвиток міжнародних стратегічних альянсів у IT-сфері, було визначено такі, що найбільшою мірою сприяли їх успіху в умовах поширення COVID-19. Здійснена видова класифікація таких факторів на основі наступних класифікаційних ознак їх поділу на внутрішні і зовнішні фактори мотивування створення та розвитку міжнародних стратегічних альянсів: за відмінностями у партнерських відносинах і організаційній культурі, за ступенем суміжності полей бізнесу, за ступенем суміжності управління, за можливостями досягнення синергетичного ефекту, за характером дій з боку керівництва, за економічною ситуацією в світі, за ступенем технологічного розвитку країн, за політичною ситуацією в світі. Рекомендований теоретико-методичний підхід взаємопов'язує та взаємодоповнює внутрішні та зовнішні фактори мотивування створення та розвитку міжнародних стратегічних альянсів у IT-сфері.

Практичне значення дослідження полягає в необхідності врахування визначених внутрішніх $\mathrm{i}$ зовнішніх факторів мотивування створення та розвитку міжнародних стратегічних альянсів у IT-сфері 3 метою виявлення ступеня їх впливу динаміку витрат і доходів IT та отримання більш достовірних результатів прогнозування їх зміни на майбутнє.

Ключові слова: стратегічний альянс, витрати IT, ринок інформачійно-комунікаиійних технологій, видова класифікація факторів успіху міжнародних стратегічних альянсів, COVID-19.

\section{SUCCESS FACTORS OF INTERNATIONAL STRATEGIC ALLIANCES IN THE IT SPHERE IN THE CONDITIONS OF COVID-19 SPREADING}

\section{Lutsk National Technical University}

International business in the IT sphere occupies an increasing share of the world market, largely due to the development of inter-firm integration and the formation of international strategic alliances. Implementation of intersectoral innovation projects, formation of new conditions of interaction between states and business, technological integration of science and production allow to successfully overcoming barriers of economic blocs and borders of countries and mastering new international sales markets.

The scientific article solved a difficult task - to carry out a classification of types of the success factors of international strategic alliances in the IT sphere in the conditions of the spread of COVID-19. Despite the large number of publications devoted to the problem of the formation and development of international strategic alliances, it was only partially disclosed, defining the subject essence of strategic alliances, organizational and legal conditions of their formation, advantages and disadvantages of creation and management specifics. The problem has not been solved at all for modern conditions - the spread of COVID-19. And equally important is to determine the factors that contribute to the success of strategic alliances in international markets.

Made analysis of the current dynamics and forecasting of global IT cost in the period of 2020-2022 revealed a significant increase in interest in the IT business sectors in the conditions of the spread of COVID-19, the formation of favorable conditions for investing in software products, compared to most companies in the world that are still experiencing declining revenues. This, of course, emphasizes the importance of studying the factors that contributed to the identified trends in the development of IT business and the role of international strategic alliances, the share of which is about $20 \%$ of their total number.

In the study of factors influencing the formation and development of international strategic alliances in the IT field, ones that contributed the most to their success in conditions of the spread of COVID-19 were identified. The classification of types of such factors was made based on following classification features of their division into internal and external factors motivating the creation and development of international strategic alliances: by the differences in partnerships and organizational culture, by the degree of contiguity of business fields, the degree of contiguity of management, by the possibilities of achieving a synergetic effect, by the nature of actions by management, by the economic situation in the world, by the degree of technological development of countries, by the political situation in the world. The recommended theoretical and methodological approach interconnects and complements the internal and external factors that motivate the creation and development of international strategic alliances in the field of IT.

The practical significance of the study is the need to take into account certain internal and external factors of motivation of the creation and development of international strategic alliances in the IT sphere in order to identify their impact on the dynamics of IT costs and revenues and obtain more reliable results for forecasting their change in the future. COVID-19.

Key words: strategic alliance, IT costs, ICT market, classification of types of the success factors of ISA, 
Постановка проблеми у загальному вигляді та іï зв'язок 3 важливими науковими та практичними завданнями. Міжнародний бізнес в IT-сфері з початку XXI століття вважається однією з найбільш перспективних галузей вкладання капіталу. Причинами цього виступають як глобалізаційні процеси, які “охоплюють практично всі сфери діяльності світового суспільства та внесли незворотні зміни в функціонування світової економіки, сформували нові умови взаємодії держав та бізнесу" [1, с. 295], так i активне створення та поширення інформаційно-комунікаційних технологій, які "формують основу технологічної інтеграції науки й виробництва, забезпечують ефективну обробку даних" [2, с. 35], сприяючи не лише переорієнтуванню бізнесу на зміни, які відбуваються на глобальних ринках, але й видозмінюють конкурентне середовище, створюючи передумови для виникнення особливих форм співробітництва на міжнародному рівні в напрямку спільного використання різних видів ресурсів, структур управління тощо. В ІT-індустрії це дозволяє більш ефективно “освоювати нові технології, здійснювати міжгалузеві новаторські проєкти, долати кордони країн та економічних блоків, освоювати міжнародні ринки збуту" [3, с. 52]. Для вітчизняних ITкомпаній, які “є прихильниками укладення міжнародних стратегічних альянсів 3 європейськими та американськими партнерами, це виступає реальною можливістю скоротити свої затрати та знизити ризики IT-бізнесу" [4, с. 477]. Вище перелічене підкреслює актуальність дослідження питань, які стосуються функціонування міжнародних стратегічних альянсів у IT-сфері.

Аналіз останніх досліджень і публікацій, в яких започатковано вирішення проблеми. Дослідженням питань особливостей формування, функціонування та розвитку міжнародних стратегічних альянсів займалось багато як вітчизняних, так й іноземних учених. Зокрема, такі науковці як Морозова I.В. і Чернова О.В., вказують на багатозначність поняття “стратегічний альянс", особливості віднесення таких альянсів до міжнародних, способи управління ними [5]. Максименко І. Я. та Єфімова М. О., вивчаючи особливості формування стратегічних альянсів на міжнародному та українському ринках, прийшли до висновку, що “використання позитивного досвіду створення стратегічних альянсів вітчизняними підприємствами дозволить оцінити і удосконалити власні виробничі і управлінські процеси і технологіі”' [6]. Касич А. О. й Чумаченко Ю. В., даючи класифікацію міжнародних стратегічних альянсів, узагальнюють їх ключові характеристики, переваги та недоліки, а також виокремлюють найбільш значущі серед альянсів, зокрема й у сфері IT [7]. Орлов В. М., Петрашевська А. Д., Драган К. Ю. та Статірова К. В. розкривають фактори формування стратегічних альянсів, пропонуючи їх поділяти на внутрішні (ресурсні, транзакційні та управлінські) і зовнішні (економічні, технологічні, політичні), які розглядають як фактори впливу на функціонування альянсів [8]. Особливості управління підприємством у складі міжнародного стратегічного альянсу визначено в дослідженнях Шевченко М. М., Назарова Т. Ю. й Донської Ю. А. [9]. Аналіз функціонування та розвитку міжнародних стратегічних альянсів у сфері IT, вивчення впливу інформаційно-комунікаційних технологій на розвиток бізнесу представлено в роботах $[1 ; 2 ; 10 ; 11]$. Не менше уваги приділяють досліджуваній проблематиці й зарубіжні вчені, роботи яких є більш різнопланові та носять прикладний характер. Masoud I. F., Buzovich A. I. та Vladimirova I. G. вивчають фактори успіху та невдач міжнародних стратегічних альянсів [12]. Проблема пошуку факторів успіху синергії на основі компетентності у стратегічних альянсах знайшла своє вирішення в роботі Čirjevskis A. [13]. У дослідженнях Drewniak R. i Karaszewski R. вказано як інновації та поширення знань сприяють покращенню функціонування міжнародних стратегічних альянсів [14; 15]. Питанням важливості створення альянсів для обміну ресурсами, технологіями та операційними ризиками присвячено статтю Fatehi K., Choi J. [16]. Li C., Reuer J. J. визначають вплив корупційних процесів на реагування ринку щодо створення міжнародних стратегічних альянсів і зростання невизначеності відносно поведінки компаній-партнерів [17]. Tjemkes B., Vos P. та Burgers K. деталізують механізм формування та управління стратегічними альянсами [18]. 
Проте, невирішеними лишаються питання вивчення факторів успіху міжнародних стратегічних альянсів, які позиціонують в IT-сфері. Враховуючи значення останньої, особливо в умовах поширення COVID-19, це $\epsilon$ важливим науковим завданням, що потребує грунтовного аналізу та дослідження.

Мета статті полягає в подальшому розвитку видової класифікації факторів успіху міжнародних стратегічних альянсів у IT-сфері в умовах поширення COVID-19.

Виклад основного матеріалу дослідження 3 повним обгрунтуванням отриманих наукових результатів. Стратегічні альянси та партнерства поступово стали одним із найважливіших інструментів щодо розширення технологічного бізнесу. Адже це забезпечує швидше охоплення майбутньої клієнтури з нижчими витратами, дозволяє покращувати якість їхнього обслуговування та нарощувати масштаби здійснюваних операцій. Це розуміють й керівники глобальних корпорацій, опитування серед яких показало, що з них 49\%! планують в майбутньому створення нових стратегічних альянсів або спільних підприємств з метою сприяння зростанню або ж підвищення прибутковості компаній [19].

IT-сферу характеризує активне створення міжнародних стратегічних альянсів, більше половини яких спрямовують свою діяльність на розроблення нового програмного забезпечення, а понад 1/4 - на продаж уже наявних продуктів і загальний комерційний розвиток. "Активне формування міжнародних стратегічних альянсів в IT-сфері $\epsilon$ наслідком значного розширення світового ринку інформаційно-комунікаційних технологій, включаючи обладнання, послуги та програмне забезпечення, а також телекомунікації" [4].

Не зважаючи на те, що ще й досі більшість компаній світу все ще зазнають скорочення доходів, витрати на інформаційні технології зростають, випереджаючи очікувані доходи [20]. Світовий ринок інформаційно-комунікаційних технологій поступово стає потужною платформою для зростання доходів інвесторів, які готові інвестувати в продукти програмного бізнесу [11, с. 156].

Динаміка та прогноз світових витрат на інформаційні технології в умовах поширення COVID-19 (у період 2020-2022 рр.) дозволяє будувати перспективні стратегії вкладання капіталу в різні сектори IT-сфери, серед яких одним 3 найбільш перспективних виступає сегмент IT-послуг, завдяки зростанню витрат на розвиток інфраструктури (таблиця 1).

Таблиця 1

Динаміка та прогноз світових витрат на IT [20]

\begin{tabular}{|c|c|c|c|c|c|c|}
\hline \multirow{3}{*}{$\begin{array}{l}\text { Сектори IT- } \\
\text { бізнесу }\end{array}$} & \multicolumn{6}{|c|}{ Період дослідження } \\
\hline & \multicolumn{2}{|c|}{2020 рік } & \multicolumn{2}{|c|}{2021 рік } & \multicolumn{2}{|c|}{2022 рік } \\
\hline & $\begin{array}{c}\text { Обсяг } \\
\text { витрат, млн } \\
\text { дол США }\end{array}$ & $\begin{array}{l}\text { Динаміка } \\
\text { зміни, \% }\end{array}$ & $\begin{array}{c}\text { Обсяг } \\
\text { витрат, млн } \\
\text { дол США }\end{array}$ & $\begin{array}{l}\text { Динаміка } \\
\text { зміни, \% }\end{array}$ & $\begin{array}{c}\text { Обсяг } \\
\text { витрат, млн } \\
\text { дол США }\end{array}$ & $\begin{array}{l}\text { Динаміка } \\
\text { зміни, \% }\end{array}$ \\
\hline Системи ЦОД & 178466 & 2,5 & 191648 & 7,4 & 201659 & 5,2 \\
\hline $\begin{array}{l}\text { Програмне } \\
\text { забезпечення } \\
\text { підприємств }\end{array}$ & 529028 & 9,1 & 598957 & 13,2 & 669114 & 11,7 \\
\hline Пристрої & 696990 & $-1,5$ & 793973 & 13,9 & 800172 & 0,8 \\
\hline IT-послуги & 1071281 & 1,7 & 1176676 & 9,8 & 1277228 & 8,5 \\
\hline Послуги зв'язку & 1396287 & $-1,4$ & 1444980 & 3,5 & 1481878 & 2,6 \\
\hline $\begin{array}{l}\text { Загалом по } \\
\text { секторах }\end{array}$ & 3872052 & 0,9 & 4206234 & 8,6 & 4430051 & 5,3 \\
\hline
\end{tabular}

Аналіз динамізму світових витрат на IT вказує, що поточний рік має принести суттєве зростання доходів на інформаційно-комунікаційні технології та послуги, що за умов зростання активності інвесторів може цілком перекрити прогнозоване падіння ITбізнесу в 2022 році. Найбільш динамічно зростаючими секторами IT у 2021 році стануть розробка та продаж програмного забезпечення для підприємств, а також 
супроводжуючих його різноманітних пристроїв. Загалом впродовж 2020-2022 років прогнозується зростання витрат на IT: з 3,87 трлн дол США у 2020 році до 4,21 трлн дол США у 2021 році та, надалі, до 4,43 трлн дол США у 2022 році. Слід відзначити, що "методологія прогнозування витрат на IT компанії Gartner значною мірою спирається на ретельний аналіз продажів тисячами постачальників у всьому спектрі IT-продуктів та послуг" [20].

На ситуацію, що складається у будь-якій сфері бізнесу, має вплив безліч внутрішніх i зовнішніх факторів. Так, в роботі таких вчених як Орлов В. М., Петрашевська А. Д., Драган К. Ю. та Статірова К. В. внутрішні фактори формування стратегічних альянсів пропонується розглядати “як мотиви компаній, що спонукають їх до стратегічної співпраці 3 конкурентами, постачальниками та споживачами на довгостроковій основі”, а зовнішні як такі, що “перебувають поза прямим впливом компаній ... і ... діють в органічному взаємозв'язку 3 факторами внутрішнього середовища" [8, с. 79]. Аналізуючи різноманітні фактори, як внутрішні, так і зовнішні, стає зрозумілим, що вони можуть впливати як на успіх міжнародних стратегічних альянсів, так і спричинювати їх невдачу.

Базуючись на критичному аналізу наукових публікацій вчених сучасності, що займались дослідженням різних сторін формування, функціонування та розвитку міжнародних стратегічних альянсів, й у т.ч. у IT-сфері $[2 ; 3 ; 4 ; 8 ; 12-17]$, нами здійснено видову класифікацію ключових факторів успіху міжнародних стратегічних альянсів у ITсфері в умовах поширення COVID-19 (таблиця 2). Разом з тим, запропонований підхід не слід вважати повністю обгрунтованим і завершеним, адже кількість та ступінь прояву факторів може змінюватись як в межах окремо обраного для дослідження стратегічного альянсу, так і з плином часу, розвитком підходів до управління та бізнес-діяльності.

Таблиця 2

Класифікація факторів успіху міжнародних стратегічних альянсів у IT-сфері в умовах поширення COVID-19

\begin{tabular}{|c|c|c|}
\hline Класифікаційна ознака & $\begin{array}{c}\text { Критерій } \\
\text { класифікації }\end{array}$ & Фактори успіху \\
\hline $\begin{array}{l}\text { 1. За відмінностями у } \\
\text { партнерських } \\
\text { відносинах і } \\
\text { організаційній культурі }\end{array}$ & $\begin{array}{l}\text { Рівень } \\
\text { розподілу } \\
\text { відносин }\end{array}$ & $\begin{array}{l}\text { - додаткові навички та знання партнерів; } \\
\text { - високий рівень відкритості партнерів; } \\
\text { - відкрите та інтерактивне спілкування між партнерами; } \\
\text { - мінімальне перекриття ринків партнерів; } \\
\text { - довіра між партнерами, визначена на договірній основі; } \\
\text { - повага до відмінностей в корпоративній культурі партнерів. }\end{array}$ \\
\hline $\begin{array}{l}\text { 2. За ступенем } \\
\text { суміжності полей } \\
\text { бізнесу }\end{array}$ & $\begin{array}{l}\text { Рівень } \\
\text { інтернаціона- } \\
\text { лізації бізнесу }\end{array}$ & $\begin{array}{l}\text { - суміжність високотехнологічних галузей та секторів партнерів за } \\
\text { бізнесом із врахуванням умов поширення COVID-19; } \\
\text { - суміжність стратегічних цілей партнерів до і після поширення } \\
\text { COVID-19; } \\
\text { - взаємозамінність методів і форм роботи на ринку залежно від } \\
\text { умов поширення COVID-19; } \\
\text { - швидкість диверсифікацї̈ бізнесу відносно поширення пандемії та } \\
\text { введених режимів карантинних обмежень у країнах партнерів; } \\
\text { - ступінь мобільності персоналу та його здатність працювати } \\
\text { дистанційно. }\end{array}$ \\
\hline $\begin{array}{l}\text { 3. За ступенем суміжності } \\
\text { управління }\end{array}$ & $\begin{array}{l}\text { Період } \\
\text { досяжності } \\
\text { цілей }\end{array}$ & $\begin{array}{l}\text { - досяжність стратегічних цілей взаємної вигоди із врахуванням } \\
\text { умов поширення COVID-19; } \\
\text { - відповідність внеску партнерів масштабам бізнесу під час } \\
\text { пандемї̈; } \\
\text { - швидкість узгодження або корегування цілей та параметрів угоди } \\
\text { в умовах поширення COVID-19. }\end{array}$ \\
\hline $\begin{array}{l}\text { 4. За можливостями } \\
\text { досягнення } \\
\text { синергетичного ефекту }\end{array}$ & $\begin{array}{c}\text { Рівень } \\
\text { додаткової } \\
\text { вартості, що } \\
\text { отримується }\end{array}$ & $\begin{array}{l}\text { - обмін доповнюючими активами та технологіями; } \\
\text { - надихаючі інновації; } \\
\text { - здатність партнерів до навчання та адаптації під час } \\
\text { впровадження; } \\
\text { - посилення оперативної інтеграції у міру розвитку стратегічного } \\
\text { альянсу. }\end{array}$ \\
\hline $\begin{array}{l}\text { 5. За характером дій } 3 \\
\text { боку керівництва }\end{array}$ & $\begin{array}{l}\text { Рівень впливу } \\
\text { посилюючих } \\
\text { факторів }\end{array}$ & $\begin{array}{l}\text { - лідерство; } \\
\text { - управління людськими ресурсами; } \\
\text { - створення колективних робочих команд. }\end{array}$ \\
\hline
\end{tabular}


Продовження таблиці 2

\begin{tabular}{|c|c|c|}
\hline 1 & 2 & 3 \\
\hline $\begin{array}{l}\text { 6. За економічною } \\
\text { ситуацією в світі }\end{array}$ & $\begin{array}{l}\text { Формування } \\
\text { умов для } \\
\text { створення } \\
\text { альянсів } \\
\end{array}$ & $\begin{array}{l}\text { - розвиток глобалізаційних процесів; } \\
\text { - виникнення факторів непередбачуваної дії; } \\
\text { - ступінь конкурентної боротьби за нові ринки; } \\
\text { - розгортання світової кризи (як можливість). }\end{array}$ \\
\hline $\begin{array}{l}\text { 7. За ступенем } \\
\text { технологічного } \\
\text { розвитку країн }\end{array}$ & $\begin{array}{c}\text { Рівень } \\
\text { технологізації } \\
\text { економік }\end{array}$ & $\begin{array}{l}\text { - прагнення оволодіння новими технологіями та знаннями; } \\
- \text { посилення позицій національних компаній на міжнародних } \\
\text { ринках; } \\
\text { - формування можливостей для обміну високотехнологічними } \\
\text { розробками та знаннями. }\end{array}$ \\
\hline $\begin{array}{l}\text { 8. За політичною } \\
\text { ситуацією в світі }\end{array}$ & $\begin{array}{l}\text { Збереження } \\
\text { національних } \\
\text { інтересів }\end{array}$ & $\begin{array}{l}\text { - збереження геополітичних інтересів країн; } \\
\text { - захист національних кордонів завдяки співпраці з країнами- } \\
\text { членами військових альянсів; } \\
\text { - розвиток експортноорієнтованої спрямованості економіки. }\end{array}$ \\
\hline
\end{tabular}

В сучасних умовах поширення COVID-19, досягнення синергії у стратегічних альянсах вже не повною мірою забезпечується функцією стратегічної сумісності, взаємодоповнюваності та передачі основних компетенцій, які сприяють внутрішнім перевагам та зовнішній релевантності основних компетенцій компаній-партнерів та підтримуються відкритим та інтерактивним спілкуванням, взаємної довіри та зобов'язань, плану інтеграції основних компетенцій та культурної відповідності ділових партнерів [13]. Значна увага повинна приділятись й таким факторам, які визначають суміжність полей бізнесу та управління в умовах поширення COVID-19 і сприяють прискоренню диверсифікації бізнесу, мобільності персоналу, удосконаленню методів і засобів управлінської діяльності (внутрішнім факторам мотивування створення та розвитку міжнародних стратегічних альянсів), а також сприяють формуванню умов для створення альянсів, підвищенню рівня технологізації економік і збереженню національних інтересів (зовнішнім факторам мотивування створення та розвитку міжнародних стратегічних альянсів).

Висновки. Критичний аналіз наукових публікацій вчених, які займаються вивченням питань формування та розвитку міжнародних стратегічних альянсів у ITсфері, вказує на недостатність дослідження факторів, які сприяють успіху стратегічних альянсів на міжнародних ринках. В сучасних умовах поширення COVID-19 це вимагає особливої уваги, адже може негативно впливати на рівень технологізації економік i збереження національних інтересів, сприяти виникненню економічної дестабілізації економік країн світу.

Аналіз динаміки світових витрат на IT дозволяє констатувати підвищення інтересу до секторів IT-бізнесу в умовах поширення COVID-19, формування сприятливих умов для інвестування в продукти програмного бізнесу. Проте, наявна ситуація вимагає грунтовного вивчення факторів, які спричинюють позитивну динаміку світових витрат на IT.

Як результат дослідження, запропоновано видову класифікацію факторів успіху міжнародних стратегічних альянсів у IT-сфері в умовах поширення COVID-19, де в якості основних класифікаційних ознак поділу внутрішніх i зовнішніх факторів мотивування створення та розвитку міжнародних стратегічних альянсів виокремлено такі: за відмінностями у партнерських відносинах і організаційній культурі, за ступенем суміжності полей бізнесу, за ступенем суміжності управління, за можливостями досягнення синергетичного ефекту, за характером дій 3 боку керівництва, за економічною ситуацією в світі, за ступенем технологічного розвитку країн, за політичною ситуацією в світі. Запропонований підхід взаємопов'язує та взаємодоповнює внутрішні та зовнішні фактори мотивування створення та розвитку міжнародних стратегічних альянсів у IT-сфері. 
Подальші розвідки та дослідження в напрямку вирішення проблем функціонування міжнародних стратегічних альянсів у ІТ-сфері буде спрямовано на вивчення їх ролі в глобалізації економічних процесів із врахуванням викликів сьогодення.

\section{Список бібліографічного опису:}

1. Кривов’язюк І.В. Інноваційна економіка : навчальний посібник. Київ: Кондор-Видавництво, 2016. 384 с.

2. Дугінець Г., Ніжейко К. Міжнародні технологічні альянси: співпраця компаній в IT-сфері. Зовнішня торгівля: економіка, фінанси, право. 2020. № 6. С. 35-47.

3. Ніжейко К. Міжнародні технологічні альянси в ІТ-сфері. Зовнішня торгівля: економіка, фінанси, право. 2021. № 3. C. 52-63.

4. Габрелян А. Ю. Особливості функціонування міжнародних стратегічних альянсів в IT-сфері. Правові системи. Науково-практичний електронний журнал, 2018. № 1/2. С. 469-478.

5. Морозова І.В., Чернова О.В. Стратегічні альянси як феномен глобальної економіки. Приазовський економічний вісник. 2020. Випуск 1 (18). С. 14-19.

6. Максименко І. Я., Сфімова М. О. Особливості формування стратегічних альянсів на міжнародному та українському ринках. Ефективна економіка. 2019. № 12. URL: http://www.economy.nayka.com.ua/?op=1\&z=7485 (дата звернення: 10.09.2021).

7. Касич А.О., Чумаченко Ю.В. Міжнародні технологічні альянси як чинник розвитку конкурентних переваг підприємства. Економіка і суспільство. 2017. Випуск 13. С. 78-83.

8. Орлов В. М., Петрашевська А. Д., Драган К. Ю., Статірова К. В. Фактори формування стратегічних альянсів. Бізнес Інформ, 2019. № 12. С. 76-81.

9. Шевченко М.М., Назарова Т.Ю., Донська Ю.А. Особливості управління підприємством у складі міжнародного стратегічного альянсу. Вісник НТУ «ХПІ». Економічні науки. 2020. № 5. С. 72-75.

10. Кривов'язюк I.В., Ліпич В.С. Сучасні інформаційні технології логістичного забезпечення інноваційності підприємства. Маркетинг в умовах розвитку цифррових технологій : матеріали всеукр. наук.-практ. інтернет-конф. (5 жовтня 2018 р). Луцьк: ІВВ Луцького НТУ, 2018. С. 229-231.

11. Strilchuk R., Kryvovyazyuk I. Market of information and communication technologies and place of Ukraine in it. Економічний форум. 2017. №2. С. 152-157.

12. Imad Fouad Khalid Masoud, Buzovich A.I., Vladimirova I.G. Factors of Success and Failures of International Strategic Alliance. Advances in Economics, Business and Management Research, 2019, Vol. 119, pp. 32-37.

13. Čirjevskis A. Exploring Critical Success Factors of Competence-Based Synergy in Strategic Alliances: The RenaultNissan-Mitsubishi Strategic Alliance. J. Risk Financial Manag., 2021, Vol. 14, 385. doi: 10.3390/jrfm14080385.

14. Drewniak R. Strategic Alliance and Process Innovation: The Moderating Role of the Alliance Duration and the Firm Size. In Bichler-Ripfel, H., Kragulj F. (eds.) Building Future Competences. Challenges and Opportunities for Skilled Crafts and Trades in the Knowledge Economy, 2020, Vol. 2, pp. 74-93.

15. Drewniak R., Karaszewski R. Diffusion of knowledge in strategic alliance: empirical evidence. Int Entrep Manag J, 2020, vol. 16, pp. 387-416. doi: 10.1007/s11365-019-00589-2.

16. Fatehi K., Choi J. International Strategic Alliance, Springer Texts in Business and Economics. International Business Management, 2019. Edition 2. Chapter 7, pp. 217-239.

17. Li C., Reuer J.J. The impact of corruption on market reactions to international strategic alliances. Journal of International Business Studies, 2021. doi: 10.1057/s41267-021-00404-7.

18. Tjemkes B., Vos P., Burgers K. Strategic Alliance Management. 2nd Edition. London, Routledge, 2017. 440 p.

19. Navigating the rising tide of uncertainty. 23rd Annual Global CEO Survey / 2020 PwC. URL: https://www.pwc.com/gx/en/ceo-survey/2020/reports/pwc-23rd-global-ceo-survey.pdf.

20. Gartner Forecasts Worldwide IT Spending to Grow 9\% in 2021. Technology Spending Enters a New Build Budget Phase. STAMFORD, Conn., July 14, 2021. Press Release / 2021 Gartner, Inc. URL: https://www.gartner.com/en/newsroom/pressreleases/2021-07-14-gartner-forecasts-worldwide-it-spending-to-grow-9-percent-2021.

\section{References:}

1. Kryvovyazyuk I.V. Innovatsiyna ekonomika. Kyyiv: Kondor-Vydavnytstvo, 2016. 384 p. [in Ukrainian].

2. Duhinets' H., Nizheyko K. Mizhnarodni tekhnolohichni al'yansy: spivpratsya kompaniy v IT-sferi. Zovnishnya torhivlya: ekonomika, finansy, pravo - Foreign trade: economics, finance, law, 2020, no. 6, pp. 35-47. [in Ukrainian].

3. Nizheyko K. Mizhnarodni tekhnolohichni al'yansy v IT-sferi. Zovnishnya torhivlya: ekonomika, finansy, pravo - Foreign trade: economics, finance, law, 2021, no. 3, pp. 52-63. [in Ukrainian].

4. Habrelyan A.Yu. Osoblyvosti funktsionuvannya mizhnarodnykh stratehichnykh al'yansiv v IT-sferi. Pravovi systemy Legal systems, 2018, no. 1/2, pp. 469-478. [in Ukrainian].

5. Morozova I.V., Chernova O.V. Stratehichni al'yansy yak fenomen hlobal'noyi ekonomiky. Pryazovs'kyy ekonomichnyy visnyk - Priazovsky Economic Bulletin, 2020, no. 1 (18), pp. 14-19. [in Ukrainian].

6. Maksymenko I.Ya., Yefimova M.O. Osoblyvosti formuvannya stratehichnykh al'yansiv na mizhnarodnomu ta ukrayins'komu rynkakh. Efektyvna ekonomika, 2019, no. 12. Available at: http://www.economy.nayka.com.ua/?op=1\&z=7485 (accessed 10.09.2021). [in Ukrainian].

7. Kasych A.O., Chumachenko Yu.V. Mizhnarodni tekhnolohichni al'yansy yak chynnyk rozvytku konkurentnykh perevah pidpryyemstva. Ekonomika i suspil'stvo, 2017, no. 13, pp. 78-83. Available at: https://economyandsociety.in.ua/journals/13_ukr/13.pdf (accessed 11.09.2021). [in Ukrainian].

8. Orlov V.M., Petrashevs'ka A.D., Drahan K.Yu., Statirova K.V. Faktory formuvannya stratehichnykh al'yansiv. Biznes Inform - Business Inform, 2019, no. 12, pp. 76-81. [in Ukrainian].

9. Shevchenko M.M., Nazarova T.Yu., Dons'ka Yu.A. Osoblyvosti upravlinnya pidpryyemstvom u skladi mizhnarodnoho stratehichnoho al'yansu. Visnyk NTU «KhPI». Ekonomichni nauky - Bulletin of NTU "KhPI". Economic sciences, 2020, no. 5, pp. 72-75. [in Ukrainian]. 
10. Kryvovyazyuk I.V., Lipych V.S. Suchasni informatsiyni tekhnolohiyi lohistychnoho zabezpechennya innovatsiynosti pidpryyemstva. Materialy vseukrayins'koyi naukovo-praktychnoyi internet-konferentsiyi «Marketynh v umovakh rozvytku tsyfrovykh tekhnolohiy». Luts'k, 2018, pp. 229-231. [in Ukrainian].

11. Strilchuk R.M., Kryvovyazyuk I.V.Market of information and communication technologies and place of Ukraine in it. Ekonomichnyy forum - Economic forum, 2017, no. 2, pp. 152-157. [in Ukrainian].

12. Imad Fouad Khalid Masoud, Buzovich A.I., Vladimirova I.G. Factors of Success and Failures of International Strategic Alliance. Advances in Economics, Business and Management Research, 2019, Vol. 119, pp. 32-37.

13. Čirjevskis A. Exploring Critical Success Factors of Competence-Based Synergy in Strategic Alliances: The RenaultNissan-Mitsubishi Strategic Alliance. J. Risk Financial Manag., 2021, Vol. 14, 385. doi: 10.3390/jrfm14080385.

14. Drewniak R. Strategic Alliance and Process Innovation: The Moderating Role of the Alliance Duration and the Firm Size. In Bichler-Ripfel, H., Kragulj F. (eds.) Building Future Competences. Challenges and Opportunities for Skilled Crafts and Trades in the Knowledge Economy, 2020, Vol. 2, pp. 74-93.

15. Drewniak R., Karaszewski R. Diffusion of knowledge in strategic alliance: empirical evidence. Int Entrep Manag J, 2020, vol. 16, pp. 387-416. doi: 10.1007/s11365-019-00589-2.

16. Fatehi K., Choi J. International Strategic Alliance, Springer Texts in Business and Economics. International Business Management, 2019. Edition 2. Chapter 7, pp. 217-239.

17. Li C., Reuer J.J. The impact of corruption on market reactions to international strategic alliances. Journal of International Business Studies, 2021. doi: 10.1057/s41267-021-00404-7.

18. Tjemkes B., Vos P., Burgers K. Strategic Alliance Management. 2nd Edition. London, Routledge, 2017. 440 p.

19. Navigating the rising tide of uncertainty. 23rd Annual Global CEO Survey / 2020 PwC. URL: https://www.pwc.com/gx/en/ceo-survey/2020/reports/pwc-23rd-global-ceo-survey.pdf.

20. Gartner Forecasts Worldwide IT Spending to Grow 9\% in 2021. Technology Spending Enters a New Build Budget Phase. STAMFORD, Conn., July 14, 2021. Press Release / 2021 Gartner, Inc. URL: https://www.gartner.com/en/newsroom/pressreleases/2021-07-14-gartner-forecasts-worldwide-it-spending-to-grow-9-percent-2021.

Дата подання публікації 14.09.2021 р.

УДК 339. 9

Korolchuk L. PhD, Associate Professor

Корольчук Л.В., к.е.н., доцент

https://orcid.org/0000-0002-2821-476X

Chernjakova G., student of the group IERsh.p.-t.-21

Faculty of Business and Law

Чернякова Ж.О., студентка групи МЕВсз-21

факультету бізнесу та права

\title{
MODEL OF EUROPEANIZATION OF MIGRANTS AS A WAY TO OVERCOME THE MIGRATION CRISIS IN EUROPEAN COUNTRIES
}

\author{
Lutsk National Technical University
}

The article examines the problem of finding ways out of European countries from the migration crisis, which is relevant and important for Ukraine as one of the main donors of migrant workers to the EU.

The existing experience of integration of migrants into the socio-economic system of European countries, which simultaneously alleviates social tensions in the communities of host countries on the emergence of "foreigners" and also allows effective use of the positive aspects of immigration, in two forms: multiculturalism and assimilation.

Based on the studied experience, empirical analysis of the Europeanization process and hypotheticaldeductive method, a model of Europeanization of migrants into European society was developed as a way to overcome the migration crisis, which involves the simultaneous application of polar forms of migration policy: liberalization and protectionism. This is due to the need for the EU in the process of overcoming the migration crisis to be able to simultaneously reap the benefits that may occur in the current situation, as well as ensure supranational and economic security of the Union, due to the real threat of uncontrolled increase in migration flows to the EU.

The grounds for introducing a model of Europeanization of migrants in the current context of the Crown virus pandemic are identified, and it is argued that the model of Europeanization of migrants will help the EU not only overcome the migration crisis and strengthen by overcoming a number of domestic socio-economic problems through migrants, but also extend European values based on democracy and respect for human rights and freedoms to other peoples, which will ensure the mental convergence of different peoples of the world and thus reduce the 